\title{
VLADIMÍR PAPOUŠEK A KOL.: Pokušení neviditelného. Myšlení moderny [The Temptation of the Invisible: The Thinking of Modernism]
}

Praha: Filip Tomáš - Akropolis, 2019. 503 s. ISBN 978-80-7470-263-1

DOI: https://doi.org/10.31577/WLS.2021.13.2.12

Autorský kolektív pod vedením Vladimíra Papouška začal výskum neviditelného reflexiou počiatočnej fázy novoveku, ktorá je avizovaná najmä talianskou renesanciou. Charakter tohto obdobia sa v dôsledku posilnenia postavenia prírodných vied profiluje na pozadí radikálnych premien $\mathrm{v}$ dovtedajších konceptoch poznávania skutočnosti, ktorých limity určovali hranice metafyziky. Karteziánsky racionalizmus postupne nahlodával relatívnu stabilitu vtedajšieho sveta usporiadaného podla stredovekého krestanského univerzalizmu. Božskú autoritu nahrádzal človek, a to na základe jeho schopnosti nahliadat do doposial' neviditelnej sféry organického aj anorganického sveta. Túžba po uchopení neviditelného stála aj v základoch novej koncepcie modernistického myslenia, ktoré už vo svojich počiatkoch predznamenáva paradigmu obdobia fin de siècle. Masívny vedecko-technický pokrok konca 19. storočia a prvej polovice 20. storočia však zároveň vedie ku „krízovým stavom“ moderny a ich intervencie do umeleckej tvorby, za ktorou stojí človek podliehajúci pokušeniu neviditelného.

Kolektívna monografia Pokušení neviditelného. Myšlení moderny zachytáva transformácie a prípadné kolapsy myslenia moderny najmä cez identifikáciu tých miest, na ktorých sa viera vo vedecké usporiadanie skutočnosti dostáva do konfliktu $s$ vierou $\mathrm{v}$ jedinečnost' človeka, ako aj s jeho slobodou. Slovami Vladimíra Papouška, „[a]bsolutní svoboda myšlení a tvoření, kterou si od modernismu slibovali, se často mění ve svěrací kazajku povinnosti a poslušnosti“ $(10$ - 11). Po Papouškovom úvodnom slove autor pokračuje vstupom do krízy modernistických popisov sveta, a to na základe kritického prístupu $\mathrm{k}$ antropocentrickej koncepcii Martina Heideggera a dobového diskurzu - prehlbujúceho sa rozporu medzi prírodnými a humanitnými vedami utvárajúcimi nové, často radikálne obrazy sveta s noetickými ambíciami. Modernistické naratívne projekcie však vznikajú ako výpovede o postavení človeka intenzívne zasahovaného realitou, ktorá $\mathrm{v}$ dôsledku objavenia nových skutočností (napr. zakriveného priestoru či paradoxov času) prestáva byt lineárna. Táto situácia nabáda k opätovnému hladaniu rovnováhy, $\mathrm{k}$ ambícii obnovit univerzálny výklad sveta, kde sa naplno uplatňuje ludská imaginácia. Papoušek tak do myslenia moderny implementuje francúzsky surrealizmus, existencializmus a psychoanalýzu ako spôsoby videnia sveta a človeka $v$ ňom, ktoré aktívne narábajú s metaforikou a naratívom, sústredenými okolo dominantnej antropocentrickej konštanty, ktorou je práve ludská bytost'. Papoušek pokračuje reflexiou medzivojnových avantgárd (dadaizmu, konštruktivizmu, poetizmu, futurizmu, artificializmu atd.) v štúdii „Infračervená a ultrafialová: Příběh jedné víry a jedné teorie“ na základe prístupov teoretika Karla Teigeho, podla ktorého ultrafialové spektrum predstavuje „jiný vstup do neviditelného světa, do skutečnosti, která je reálná, ale zároveň zůstává skrytá bez nové konstrukční aktivity subjektu“ (216 - 217). Autor zároveň otvára problematiku obojstranných presahov estetiky a spoločenského diania, resp. politických ideí. V predstave moderného nezastavitel'ného pohybu smerom $k$ lepšej a dokonalejšej budúcnosti sa postupne začínajú objavovat trhliny, a to jednak v rovine slovníka, ktorý stráca svoju konštrukčnú stabilitu, ale aj v nepoužitelnosti nových paradigiem v reálnom živote a konfrontácii ideálu so skutočnostou. Papoušek v štúdii „Drolící se monolity, zakřivené horizonty a hledání no- 
vého slovníku: Pochybnosti o moderně od čtyřicátých let dvacátého století “ zachytáva práve posun od modernistických monolitov a ideálnych projekcií $\mathrm{k}$ reflexii porúch a odchýlok, a to cez osobnosti Bohuslava Brouka, Václava Navrátila, Jindřicha Chalupeckého či Milady Součkovej.

$\mathrm{V}$ kontexte prvej polovice 20. storočia s neviditelným bezprostredne súvisí oblast' nevypovedatelného, nevyslovitel'ného, teda toho, čo nie je možné uchopit prostredníctvom slov a reči. Vedomie devalvácie a vyprázdnenosti slova napokon stojí aj na začiatku epochálnej krízy umenia a kultúry nového storočia. Kríza moderny je tak zároveň aj krízou jazyka, čo však značí zrod estetických inovácií ranej avantgardy a novotvarov, ktorých obsah zostáva skrytý. Kaleidoskopickému triešteniu starého sveta na fragmenty cez optiku modernej poézie, ktorej reflexia osciluje medzi hermeneutikou a fenomenológiou, sa v druhej štúdii venuje Josef Vojvodík.

David Skalický, autor štúdie „Myšlení o literatuře mezi uměním a vědou“, zachytáva pojmové pole pražskej štrukturalistickej estetiky s cielom priblížit jeden zo spôsobov odborného myslenia o literatúre, ktorý dominuje práve v období implementovania pojmu moderna do systému českých literárnovedných pojmov. Skalický vytvára metodologický prierez českou literárnou kritikou cez úvahy J. Karáska, F. X. Šaldu, A. Nováka či K. Čapka o metódach a spôsoboch uvažovania o literatúre, ktorých cielom je objektívne vedecké poznanie s dôrazom na štruktúru textu a jeho estetickú kompozíciu.

Myslenie o literatúre je v štúdii Ondřeja Pešeka konkretizované na uvažovanie o jazyku ako súčasti moderného českého jazykovedného diskurzu $\mathrm{v}$ dobovom kontexte moderny s ohladom na limity jednotlivých metodologických modelov. Vychádzajúc z kvalitatívnej revolúcie v jazykovedných prístupoch prvej polovice 20. storočia sa autor štúdie zameriava predovšetkým na dejiny (jazykovedného) myslenia, ktoré sa odvíjajú od spôsobov lingvistických analýz korpusu textov produkujúcich význam a smerujú až ku kvantitatívnym a kvalitatívnym textovým analýzam na základe využitia komputačných nástrojov (napr. program QUITA alebo TXM).

Od možností počítačom asistovaných analýz sa svojou štúdiou výrazne odkláňa Veronika Čejková, a to situovaním fantázie ako základného prostriedku poznania na miesta, kde skutočnost’ nemožno vyjadrit' slovami. Roky 1917 - 1925 sú pre rozvoj českej fantastiky, idúcej za hranice formy a výrazu, zlomovým obdobím. Nové tendencie vo výtvarnom aj literárnom umení sa odvíjajú od mimetického vztahu medzi fantáziou a skutočnostou a smerujú k vytvoreniu novej, doposial' skrytej skutočnosti. Autorka tak približuje líniu magického realizmu a naň nadväzujúce aktivity Devětsilu, fantastickú prózu českej avantgardy a tzv. novej moderny na základe modifikácie mimesis na tvorivú poiesis.

Umelecká obrazotvornost', ktorá v avantgarde mnohokrát prekračuje hranice ludského vedomia, podla Marie Langerovej vzniká ruka $\mathrm{v}$ ruke s hladaním hraníc slobody človeka a s prieskumom časovosti jeho existencie. Už samotný názov autorkinej štúdie „Obraz a svoboda“ naznačuje proces experimentálneho odhalovania nevedomia cez jeho prítomnost' $v$ umeleckom diele, obzvlášt' v surrealizme. V modernom umení 20. storočia sa čoraz intenzívnejšie prejavuje spätost' s psychoanalýzou Sigmunda Freuda či filozofiou Henriho Bergsona, čo otvára možnost’ nových obrazových reprezentácií založených na vyjadrení dynamiky, pohybu, ako aj na zdôraznení anachronických momentov nepodliehajúcich cenzúre. Langerová pokračuje štúdiou „Obraz a skutečnost“, v ktorej približuje deformujúcu silu obrazu ako súčasti jazykového vyjadrenia (napr. v tvorbe Richarda Weinera), a tak smeruje $\mathrm{k}$ odhalovaniu zmyslu moderného umenia ako mentálneho obrazu.

Michal Bauer od surrealizmu prechádza $\mathrm{k}$ reflexii domácej diskusie o slobode umenia $\mathrm{v}$ socialistickom realizme $\mathrm{v}$ českom kultúrnom prostredí druhej polovice 30 . rokov 20. storočia. Politicko-ideologická intervencia do umeleckej tvorby opätovne otvára otázky 
o možnostiach a limitoch sebarealizácie a zároveň produkuje rôzne prístupy $\mathrm{k}$ snahám o estetizáciu ideológie. Autor v predmetnej štúdii napokon zdôrazňuje, že na miestach, kde sa ideologické konštrukty sveta stávajú neudržatelnými, opät vystupuje umelecká tvorba ako autentický tvorivý proces.

Rozsiahla monografia je ukončená uchopením moderny v časovom horizonte rokov 1895 - 1947 s dôrazom na reflexiu premien dobového myslenia cez domáce a zahraničné impulzy, čím autorský kolektív edične nadviazal na metódu pozorovania literárnych dejín cez pole literárneho a kultúrneho diania uplatnenú v trojzväzkových Dějinách nové moderny (Papoušek a kol. 2010, 2014, 2017).

ZUZANA KOPECKÁ Ústav svetovej literatúry SAV Slovenská republika 